\title{
ZAVRŠNI RADOVI U VISOKOGRADNJI - PLANIRANJE TROŠKOVA
}

\section{Mario Galić}

Sveučilište J. J. Strossmayera u Osijeku Građevinski fakultet Osijek, dipl.ing.građ.

\section{Zlata Dolaček-Alduk}

Sveučilište J. J. Strossmayera u Osijeku Građevinski fakultet Osijek, docentica

\section{Dalibor Burilo}

Sveučilište J. J. Strossmayera u Osijeku Građevinski fakultet Osijek, student 1. godine sveučilišnog diplomskog studija

\section{Antonio Knežević}

Sveučilište J. J. Strossmayera u Osijeku Građevinski fakultet Osijek, student 3. godine sveučilišnog preddiplomskog studija

Sažetak: U članku se razmatra grupa završnih radova, te utjecaj tih radova na financijsko planiranje građevinskih projekata. Analizirani su izvedeni projekti na području Republike Hrvatske, pri čemu su razmatrani završni radovi na adaptacijama postojećih stambenih zgrada i završni radovi kod novoizgrađenih stambenih zgrada. S aspekta financijskog planiranja razmatrani su odnosi utrošaka resursa karakterističnih stavki troškovnika najčešćih vrsta radova koje spadaju u grupu završnih radova, te udio završnih radova u ukupnoj cijeni koštanja građevine. U radu su analizirani raspon i udjeli troškova završnih radova prema prihvaćenoj podjeli radova u građevinskim projektima, s ciljem spoznaja o kretanju i planiranju troškova završnih radova u građevinarstvu.

Ključne riječi: završni radovi; financijsko planiranje; odnos utrošaka resursa

\section{FINISHING WORKS IN CONSTRUCTION - COST PLANNING}

Abstract: Article analyzes a group of the finishing works, and their impact on the time and financial planning of construction projects. Analyzed projects are completed construction projects on the territory of Croatia, in which were considered finishing works in cases of adaptation of the existing buildings and finishing works in case of the newly constructed residential high-rise buildings. From the point of financial planning considered were related consumption of resources of the typical items in the cost estimating of the most frequent type of finishing works, and share of the cost of finishing works in the cost price of the complete construction. The paper analyzes the range and shares the finishing work costs according to by the division of work in construction projects with the aim of understanding the trends and planning of costs of finishing works in construction.

Key words: finishing works; financial planning; relation of the consumption of resources 


\section{Uvod}

Ovisno o aspektu razmatranja radova, razni autori, a i građevinska praksa, dijele građevinske radove prema najlogičnijim organizacijskim podjelama. U krugovima koji proučavaju znanstvenu granu organizacija i tehnologija građenja, najčešće spominjana (citirana) podjela građevinskih radova je ona iz knjige profesora Klepca Organizacija građenja iz 1988. godine, koji potrebne radove na izgradnji građevina dijeli na tri osnovne grupe: osnovni ili grubi građevinski radovi, završni ili zanatski građevinski radovi i građevinsko-instalaterski radovi [1]. Dalje se završni ili zanatski radovi dijele na: stolarske radove, bravarske, limarske, staklarske, keramičarske i pećarske, teracerske, soboslikarske, kamenorezačke radove, polaganje podova, izolaterske radove, tapetarske i ostale radove [1]. Pregledom literature koja se bavi problematikom kalkulacija u građevinarstvu, utvrđeno je da se pojam zanatskih radova ili obrtničkih radova postupno zamjenjuje pojmom završnih radova. Stoga je definicija da su to radovi u završnoj fazi građenja, odnosno rekonstrukcije, i popravci oštećenja nastalih za vrijeme uporabe građevine, vrlo dobro prihvaćena [2].

Vrste radova koje se pribrajaju završnim radovima nisu uvijek jasno odijeljene, što je uvjetovano razvojem i primjenom novih materijala i tehnologija, no prihvaćeno je da u tu skupinu pripadaju: teracerski, fasaderski, kamenorezački, gipsarski, keramičarski, soboslikarski, ličilački, tapetarski, krovopokrivački, podopolagački, parketarski, izolaterski (hidro, termo i zvučne izolacije), bravarski, limarski, stolarski, roletarski, staklorezački, radovi na antikorozijskoj zaštiti i drugi [2], [3]. Prema biltenu Standardna kalkulacija radova u visokogradnji iz 1998. godine, u završne radove ubrajaju se teracerski, keramičarski radovi, podovi, soboslikarski i ličilački radovi, tapetarski radovi, oblaganje drvenim, kamenim i umjetnim pločama, te završno-montažerski radovi.

Kako bi podjela bila funkcionalna, završne radove treba analizirati istovremeno i s aspekta vremenskog i financijskog planiranja, dok s aspekta postizanja optimalne kvalitete obrtničkih radova podjela mora biti u funkciji planiranja troškova i vremena istovremeno.

Važnost obrtničkih radova leži u činjenici da su to radovi čija kvaliteta izvedbe oblikuje ukupni dojam o građevini. Također treba primijetiti i činjenicu da su očekivani rasponi uporabnog vijeka puno manji za materijale koji se upotrebljavaju za izvedbu građevnih elemenata završnih radova, nego što je to kod konstrukcijskih dijelova građevine (tako npr. armirani beton vanjskih zidova ima očekivani raspon uporabnog vijeka 60-80 godina, zid od prirodnog kamena 60-250 godina, unutrašnji zidovi od betona, prirodnog kamena, opeke 100-150 godina, a vanjski premazi, ovisno o vrsti, od 6-30 godina; drvene podne obloge traju 30-50 godina, gipskartonski pregradni zidovi 30-60 godina, toplinska izolacija 25-35 godina, lak 8-10 godina, tekstil 8-20 godina) [4] [5].

Razvojem tehnologija i materijala u građevinarstvu, kao i sve rigoroznijim mjerama u vidu podizanja energetsko-ekološke svijesti društva općenito, važnost i kvaliteta završnih radova se konstantno mijenja. Promjena je u smjeru rasta udjela završnih radova, što se naravno ne odnosi na sve vrste radova u grupi završnih radova (ne odnosi se na tradicionalne radove i radove koji se sve manje izvode).

\section{Metodologija istraživanja}

Podjela svih građevinskih radova na građevinsko-obrtničke i građevinsko-instalaterske radove, a zatim građevinsko-obrtničkih na građevinske i obrtničke radove, produkt je iskustva tijeka građenja kako u pogledu vremenskog planiranja radova, tako i u pogledu financijskog planiranja. Bitno je na pravilan način dijeliti troškove radi njihovog vremenskog povezivanja. Podjela troškova prije same gradnje, u fazi koncipiranja projekta, daje jasniji uvid u strukturiranje projekta, a kasnije i ugovaranje.

Planiranje troškova građevinskih radova se u fazi koncipiranja projekta postavlja kao jedan od najvažnijh kriterija na osnovi kojeg se donosi investicijska odluka, stoga vrlo je važno što ranije i što točnije predvidjeti troškove građenja. Kako bismo imali što točniju sliku troškova grupe završnih radova, u radu smo posebno analizirali građevinske projekte i troškove završnih radova na projektima adaptacija postojećih građevina i novoizgrađenih građevina. Da bismo mogli što točnije odrediti udjele troškova završnih radova u odnosu na grube građevinske radove, promatrali smo projekte prema konačnoj namjeni tih građevina, tako da smo formirali grupe projekata i među njima odredili da će se u daljnjoj analizi razmatrati adaptirani i novoizgrađeni stambeni objekti. Promatrati općenito udjele troškova bez obzira na namjenu građevine ili neki drugi kriterij nema smisla, jer su prevelike razlike između pojedinih projekata. Npr., jasno je da završni radovi u privatnoj i javnoj investiciji ne 
mogu biti uspoređivani međusobno, jer ni sam način ugovaranja nije isti (u javnim namjenama najčešće je investitor i javni sektor, što znači da je prilikom odabira izvođača i materijala glavni kriterij - najniže cijene, dok u privatnom sektoru to ne mora biti slučaj).

$\mathrm{U}$ radu su analizirane konačne obračunske situacije izvedenih i naplaćenih radova, posebno projekti adaptacija stambenih zgrada i posebno projekti novoizgrađenih stambenih zgrada. Motivacija i očekivanje istraživanja su sljedeći: odrediti raspon i udjele troškova završnih radova prema prihvaćenoj podjeli radova u navedenim projektima, odgovoriti na pitanje ovisi li udio troškova završnih radova o ukupnom trošku građevinskoobrtničkih radova, te prema tome donijeti zaključak o kretanju i planiranju troškova završnih radova u građevinarstvu.

\section{Analiza udjela troškova završnih radova u grupi građevinsko-obrtničkih radova}

\subsection{Udio troškova završnih radova u projektima adaptacija stambenih zgrada}

Adaptacija objekata je zakonom definirana kao sanacija i svako drugo izvođenje radova kojima se utječe na ispunjavanje bitnih zahtjeva za građevinu, ali kojima se ne mijenja usklađenost građevine s lokacijskim uvjetima u skladu s kojima je izgrađena [6]. Dakle, adaptacija može podrazumijevati i održavanje građevine u vidu očuvanja bitnih zahtjeva za građevinu. Gledano kroz prizmu planiranja troškova građevinskih radova, svaka pojedina građevina bi, ovisno o njezinom stanju, zahtijevala određene mjere i radnje, a samim time bi i grupe radova bile drugačije u svakom pojedinom slučaju (negdje bi se uz sanaciju konstrukcije sanirali i podovi, negdje i pročelja i slično). Uspoređivati projekte adaptacija zahtijeva reprezentativnost i mogućnost asocijacije primjera. No, kako bismo potvrdili našu pretpostavku, u tablici 1 smo prikazali na spomenutim razmatranim projektima udjele i raspršenje udjela završnih radova u grupi građevinsko-obrtničkih radova.

Tablica 1 - Udjeli završnih radova u grupi građevinsko-obrtničkih radova pri adaptaciji stambenih zgrada

\begin{tabular}{|c|c|c|c|c|}
\hline $\begin{array}{c}\text { vrsta } \\
\text { zahvata }\end{array}$ & namjena građevine & $\begin{array}{c}\text { građevinsko-obrtnički radovi } \\
{[\mathrm{kn}]}\end{array}$ & $\begin{array}{c}\text { obrtnički radovi } \\
{[\mathrm{kn}]}\end{array}$ & $\begin{array}{c}\text { udio obrtničkih radova } \\
{[\%]}\end{array}$ \\
\hline \multirow{14}{*}{$\begin{array}{l}: \frac{\pi}{0} \\
\frac{\pi}{0} \\
\frac{\pi}{0} \\
\frac{\pi}{\pi}\end{array}$} & stambena zgrada & $6.147 .085,80$ & $2.523 .038,00$ & $41,04 \%$ \\
\hline & stambena zgrada & $5.364 .824,09$ & $2.053 .721,03$ & $38,28 \%$ \\
\hline & stambena zgrada & $2.194 .888,17$ & $1.530 .143,82$ & $69,71 \%$ \\
\hline & stambena zgrada & $1.782 .455,62$ & $1.263 .164,23$ & $70,87 \%$ \\
\hline & stambena zgrada & $1.470 .015,60$ & $1.029 .806,90$ & $70,05 \%$ \\
\hline & stambena zgrada & 1.093 .695 .99 & $679.393,05$ & $62,12 \%$ \\
\hline & stambena zgrada & $1.077 .454,15$ & $660.570,83$ & $61,31 \%$ \\
\hline & stambena zgrada & $1.040 .930,29$ & $647.948,78$ & $62,25 \%$ \\
\hline & stambena zgrada & $753.133,68$ & $543.665,60$ & $72,19 \%$ \\
\hline & stambena zgrada & $566.693,90$ & $388.469,00$ & $68,55 \%$ \\
\hline & stambena zgrada & $562.407,93$ & $406.592,15$ & $72,29 \%$ \\
\hline & stambena zgrada & $238.409,67$ & $94.832,76$ & $39,78 \%$ \\
\hline & stambena zgrada & $204.289,43$ & $90.859,14$ & $44,48 \%$ \\
\hline & stambena zgrada & $196.494,83$ & $77.865,29$ & $39,63 \%$ \\
\hline
\end{tabular}

Kao što je vidljivo u tablici 1, udio završnih radova na promatranim projektima se kreće od 38-73\%, što je prilično velik raspon podataka. Isto tako, vidljivo je da nema korelacije između ukupnog iznosa građevinsko obrtničkih radova i udjela završnih radova. Jasno je, dakle, da je vrlo nezahvalno i neprecizno uspoređivati završne radove na različitim projektima koji su iste namjene i klasificirani su adaptacijom ili čak i održavanjem građevine. Zaključak financijskog planiranja troškova kod ovakvih projekata je taj da se planovi i iskustva trebaju sagledavati u domeni tog istog projekta, te iskustava na projektima koji su međusobno slični prema nizu drugih parametara, ne samo namjeni i vrsti zahvata kao što se u ovome radu promatralo. To ne znači da u takvim slučajevima ne treba ili se ne mogu financijski planirati završni radovi, već samo da je to puno kompleksniji i zahtjevniji slučaj. 


\subsection{Udio troškova završnih radova u projektima novoizgrađenih stambenih zgrada}

U dosadašnjim istraživanjima pokazano je kako se udio završnih radova u grupi građevinsko-obrtničkih radova kreće između 11-13\% [7], no nije klasificirano koje su vrste radova uračunate pod završne radove. Uz sličnu klasifikaciju koju smo prihvatili u ovome radu, postotak je dan u drugom izvoru s 25,35\% [8]. Kako bismo usporedili odnose prethodnih istraživanja, prikazat ćemo u tablici 2 odnose završnih radova u grupi završnih radova za spomenute i opisane projekte novoizgradnje stambenih zgrada.

Tablica 2 - Udjeli završnih radova u grupi građevinsko-obrtničkih radova pri novoizgradnji stambenih zgrada

\begin{tabular}{|c|c|c|c|c|}
\hline $\begin{array}{c}\text { vrsta } \\
\text { zahvata }\end{array}$ & namjena građevine & $\begin{array}{c}\text { građevinsko-obrtnički radovi } \\
{[\mathrm{kn}]}\end{array}$ & $\begin{array}{c}\text { završni radovi } \\
{[\mathrm{kn}]} \\
\end{array}$ & $\begin{array}{c}\text { udio završnih radova } \\
{[\%]}\end{array}$ \\
\hline \multirow{8}{*}{ 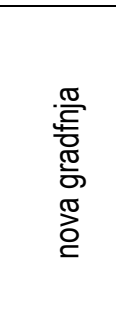 } & stambena zgrada 1 & $10.369 .553,99$ & $3.831 .057,46$ & $36,95 \%$ \\
\hline & stambena zgrada 2 & $9.978 .412,72$ & $4.848 .887,93$ & $48,59 \%$ \\
\hline & stambena zgrada 3 & $5.651 .172,62$ & $1.848 .593,46$ & $32,71 \%$ \\
\hline & stambena zgrada 4 & $5.239 .387,93$ & $2.313 .000,31$ & $44,15 \%$ \\
\hline & stambena zgrada 5 & $3.689 .412,25$ & $1.112 .984,40$ & $30,17 \%$ \\
\hline & stambena zgrada 6 & $1.826 .216,72$ & $878.851,72$ & $48,12 \%$ \\
\hline & stambena zgrada 7 & $1.673 .750,01$ & $710.839,27$ & $42,47 \%$ \\
\hline & stambena zgrada 8 & $872.145,11$ & $362.927,70$ & $41,61 \%$ \\
\hline
\end{tabular}

Prema tablici 2 primjećuje se da se udio završnih radova kreće između 30-49\%, što se značajno razlikuje od dosadašnjih istraživanja. Razlog leži u tome što se pri ovome izračunu udjela, klasifikacija završnih radova radila prema danom primjeru i izvoru [1]. Također, zanimljivo je primijetiti da ne postoji korelacija između ukupnog iznosa građevinsko-obrtničkih radova i udjela završnih radova, što znači da se može promatrati udio završnih radova bez obzira na veličinu zahvata. Da bismo to potvrdili, trebamo sagledati udjele vrsta radova koji su uračunati u završne radove i utvrditi koje su to vrste radova u završnim radovima koje nose glavninu troška (tablica 3).

Zanimljiv je i prikaz udjela završnih radova u izračunu troškova novoizgrađenog stambenog objekta prikazanog prema prodajnoj cijeni $\mathrm{m}^{2}$ stambenog prostora (slika 1), gdje je vidljivo da prema ukupnoj srednjoj cijeni kvadrata stambenog prostora od cca $9.000,00 \mathrm{kn} / \mathrm{m}^{2}$, udio građevinske izgradnje i dobiti izvođača iznosi oko $6.500,00 \mathrm{kn} / \mathrm{m}^{2}$ što je $72 \%$, i to onda usporediti s prikazanim podatcima u tablici 2 . To bi značilo da završni radovi u projektu novoizgrađenog stambenog projekta, tj. prodajnoj cijeni istog, nose između 1.950,00 - 3.185,00 kn, a to je već značajni udio koji se mora posebno uzimati u obzir prilikom planiranja troškova građenja.

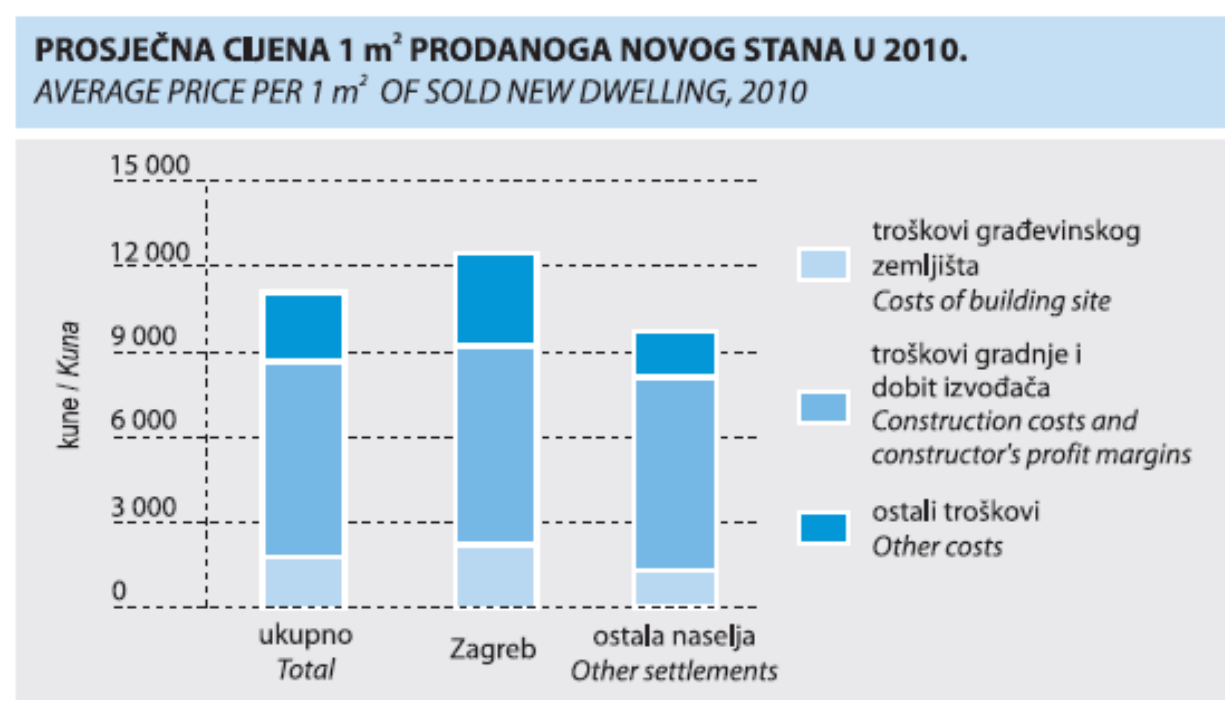




\section{Slika 1 - Prosječna prodajna cijena u stanogradnji [9]}

Tablica 3 - Udjeli završnih radova u grupi građevinsko-obrtničkih radova pri novoizgradnji stambenih zgrada

\begin{tabular}{|c|c|c|c|c|}
\hline $\begin{array}{c}\text { namjena } \\
\text { građevine }\end{array}$ & vrste radova & iznos [kn] & $\begin{array}{c}\text { odnos grubih } \\
\text { građevinskih i } \\
\text { završnih radova }\end{array}$ & udio završnih radova \\
\hline \multirow{11}{*}{$\begin{array}{l}\bar{\sigma} \\
\frac{\pi}{0} \\
\frac{\pi}{0} \\
N \\
\mathbb{N} \\
\frac{D}{0} \\
\frac{D}{0} \\
\frac{0}{E} \\
\frac{\pi}{\omega}\end{array}$} & Ukupno & $10.369 .553,99$ & $100 \%$ & \\
\hline & Građevinski radovi & $6.538 .496,53$ & $63,05 \%$ & \\
\hline & Završni radovi & $3.831 .057,46$ & $36,95 \%$ & \\
\hline & - stolarski radovi & $998.198,00$ & & $26,06 \%$ \\
\hline & - fasaderski radovi & $706.819,72$ & & $18,45 \%$ \\
\hline & - keramičarski radovi & $642.112,48$ & & $16,76 \%$ \\
\hline & - parketarski radovi & $438.682,75$ & & $11,45 \%$ \\
\hline & - izolaterski radovi & $365.640,15$ & & $9,54 \%$ \\
\hline & - bravarski radovi & $291.886,00$ & & $7,62 \%$ \\
\hline & - limarski radovi & $194.313,00$ & & $5,07 \%$ \\
\hline & - soboslikarski radovi & $193.405,46$ & & $5,05 \%$ \\
\hline
\end{tabular}

\begin{tabular}{|c|c|c|c|c|}
\hline \multirow{12}{*}{ 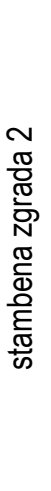 } & Ukupno & $9.978 .412,72$ & $100 \%$ & \\
\hline & Građevinski radovi & $5.129 .524,79$ & $51,41 \%$ & \\
\hline & Završni radovi & $4.848 .887,93$ & $48,59 \%$ & \\
\hline & - bravarski radovi & $1.744 .925,77$ & & $35,99 \%$ \\
\hline & - kamenorezački radovi & $1.056 .981,80$ & & $21,80 \%$ \\
\hline & - keramičarski radovi & $626.781,51$ & & $12,93 \%$ \\
\hline & - izolaterski radovi & $499.558,79$ & & $10,30 \%$ \\
\hline & - krovopokrivački radovi & $224.647,09$ & & $4,63 \%$ \\
\hline & - fasaderski radovi & $204.856,44$ & & $4,22 \%$ \\
\hline & - soboslikarski radovi & $195.607,37$ & & $4,03 \%$ \\
\hline & - limarski radovi & $148.402,60$ & & $3,06 \%$ \\
\hline & - montažni radovi (suha gradnja) & $147.126,56$ & & $3,03 \%$ \\
\hline
\end{tabular}

\begin{tabular}{|c|c|c|c|c|}
\hline \multirow{12}{*}{ 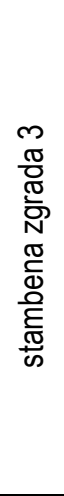 } & Ukupno & $5.651 .172,62$ & $100 \%$ & \\
\hline & Građevinski radovi & $3.802 .579,16$ & $67,29 \%$ & \\
\hline & Završni radovi & $1.848 .593,46$ & $32,71 \%$ & \\
\hline & - stolarski radovi & $449.950,00$ & & $24,34 \%$ \\
\hline & - keramičarski radovi & $344.601,24$ & & $18,64 \%$ \\
\hline & - fasaderski radovi & $280.402,35$ & & $15,17 \%$ \\
\hline & - parketarski radovi & $278.460,00$ & & $15,06 \%$ \\
\hline & - izolaterski radovi & $187.984,37$ & & $10,17 \%$ \\
\hline & - soboslikarski radovi & $146.790,10$ & & $7,94 \%$ \\
\hline & - limarski radovi & $95.216,00$ & & $5,15 \%$ \\
\hline & - bravarski radovi & $52.872,90$ & & $2,86 \%$ \\
\hline & - kamenorezački radovi & $12.316,50$ & & $0,67 \%$ \\
\hline \multirow{10}{*}{ 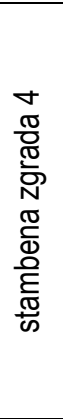 } & Ukupno & $5.239 .387,93$ & $100 \%$ & \\
\hline & Građevinski radovi & $2.926 .387,62$ & $55,85 \%$ & \\
\hline & Završni radovi & $2.313 .000,31$ & $44,15 \%$ & \\
\hline & - stolarski radovi & $768.399,91$ & & $33,22 \%$ \\
\hline & - keramičarski radovi & $326.670,14$ & & $14,12 \%$ \\
\hline & - fasaderski radovi & $322.641,11$ & & $13,95 \%$ \\
\hline & - montažni radovi (suha gradnja) & $176.651,44$ & & $7,64 \%$ \\
\hline & - izolaterski radovi & $144.485,24$ & & $6,25 \%$ \\
\hline & - soboslikarski radovi & $138.507,61$ & & $5,99 \%$ \\
\hline & - krovopokrivački radovi & $134.822,87$ & & $5,83 \%$ \\
\hline
\end{tabular}




\begin{tabular}{|c|c|c|c|c|}
\hline & - bravarski radovi & $88.407,21$ & & $3,82 \%$ \\
\hline & - parketarski radovi & $86.836,86$ & & $3,75 \%$ \\
\hline & - kamenorezački radovi & $68.601,09$ & & $2,97 \%$ \\
\hline & - limarski radovi & $56.976,83$ & & $2,46 \%$ \\
\hline $\begin{array}{c}\text { namjena } \\
\text { građevine }\end{array}$ & vrste radova & iznos $[k n]$ & $\begin{array}{c}\text { odnos grubih } \\
\text { građevinskih i } \\
\text { završnih radova }\end{array}$ & udio završnih radova \\
\hline \multirow{12}{*}{ 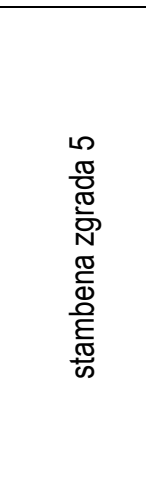 } & Ukupno & $3.689 .412,25$ & $100 \%$ & \\
\hline & Građevinski radovi & $2.576 .427,84$ & $69,83 \%$ & \\
\hline & Završni radovi & $1.112 .984,41$ & $30,17 \%$ & \\
\hline & - fasaderski radovi & $405.303,82$ & & $36,42 \%$ \\
\hline & - stolarski radovi & $352.809,60$ & & $31,70 \%$ \\
\hline & - izolaterski radovi & $115.740,02$ & & $10,40 \%$ \\
\hline & - soboslikarski radovi & $85.682,16$ & & $7,70 \%$ \\
\hline & - krovopokrivački radovi & $54.401,74$ & & $4,89 \%$ \\
\hline & - keramičarski radovi & $48.909,32$ & & $4,39 \%$ \\
\hline & - limarski radovi & $22.510,71$ & & $2,02 \%$ \\
\hline & - montažni radovi (suha gradnja) & $17.127,04$ & & $1,54 \%$ \\
\hline & - bravarski radovi & $10.500,00$ & & $0,94 \%$ \\
\hline
\end{tabular}

\begin{tabular}{|c|c|c|c|c|}
\hline \multirow{12}{*}{ 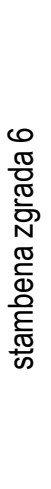 } & Ukupno & $1.826 .216,72$ & $100 \%$ & \\
\hline & Građevinski radovi & $947.365,00$ & $51,88 \%$ & \\
\hline & Završni radovi & $878.851,72$ & $48,12 \%$ & \\
\hline & - stolarski radovi & $320.551,15$ & & $36,47 \%$ \\
\hline & - fasaderski radovi & $150.550,00$ & & $17,13 \%$ \\
\hline & - bravarski radovi & $83.709,25$ & & $9,52 \%$ \\
\hline & - izolaterski radovi & $82.589,11$ & & $9,40 \%$ \\
\hline & - keramičarski radovi & $73.275,69$ & & $8,34 \%$ \\
\hline & - parketarski radovi & $70.132,84$ & & $7,98 \%$ \\
\hline & - limarski radovi & $46.245,75$ & & $5,26 \%$ \\
\hline & - soboslikarski radovi & $32.973,71$ & & $3,75 \%$ \\
\hline & - montažni radovi (suha gradnja) & $18.824,22$ & & $2,14 \%$ \\
\hline
\end{tabular}

\begin{tabular}{|c|c|c|c|c|}
\hline \multirow{12}{*}{ 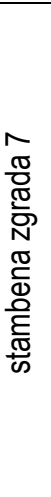 } & Ukupno & $1.673 .750,01$ & $100 \%$ & \\
\hline & Građevinski radovi & $962.910,74$ & $57,53 \%$ & \\
\hline & Završni radovi & $710.839,27$ & $42,47 \%$ & \\
\hline & - stolarski radovi & $192.700,00$ & & $27,11 \%$ \\
\hline & - fasaderski radovi & $138.245,54$ & & $19,45 \%$ \\
\hline & - keramičarski radovi & $117.056,74$ & & $16,47 \%$ \\
\hline & - izolaterski radovi & $65.323,07$ & & $9,19 \%$ \\
\hline & - parketarski radovi & $55.367,00$ & & $7,79 \%$ \\
\hline & - bravarski radovi & $51.136,00$ & & $7,19 \%$ \\
\hline & - krovopokrivački radovi & $31.305,70$ & & $4,40 \%$ \\
\hline & - soboslikarski radovi & $30.540,60$ & & $4,30 \%$ \\
\hline & - limarski radovi & $29.164,62$ & & $4,10 \%$ \\
\hline
\end{tabular}

\begin{tabular}{|c|c|c|c|c|}
\hline \multirow{10}{*}{ 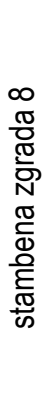 } & Ukupno & $872.145,11$ & $100 \%$ & \\
\hline & Građevinski radovi & $509.217,41$ & $58,39 \%$ & \\
\hline & Završni radovi & $362.927,70$ & $41,61 \%$ & \\
\hline & - stolarski radovi & $88.329,00$ & & $24,34 \%$ \\
\hline & - fasaderski radovi & $85.472,00$ & & $23,55 \%$ \\
\hline & - izolaterski radovi & $51.991,00$ & & $14,33 \%$ \\
\hline & - keramičarski radovi & $42.837,50$ & & $11,80 \%$ \\
\hline & - parketarski radovi & $34.298,80$ & & $9,45 \%$ \\
\hline & - limarski radovi & $24.790,50$ & & $6,83 \%$ \\
\hline & - bravarski radovi & $21.000,00$ & & $5,79 \%$ \\
\hline
\end{tabular}




\begin{tabular}{|l|l|r|r|}
\hline & - soboslikarski radovi & $14.208,90$ & $3,92 \%$ \\
\hline
\end{tabular}

Prema tablici 3 vidljivo je da su karakteristične vrste radova,a koje pripadaju završnim radovima pri novoizgradnji stambenih zgrada, izolaterski, stolarski, soboslikarski i ličilački, bravarski, keramičarski, parketarski, fasaderski, limarski i kamenorezački radovi.

Prema Paretovom pravilu [10], tri stavke nose otprilike $80 \%$ udjela završnih radova u svakom pojedinom promatranom projektu. Vrlo je zanimljivo da su to radovi na fasadama uz izolacije (fasaderski radovi), prozori i vrata (stolarski i/lil bravarski radovi) i završna obrada podova (parketarski i/lil keramičarski, kamenorezački radovi).

Naravno, u daljnjem istraživanju poželjno je proučiti i analizirati što veći broj projekata, no vidljivo je da i pri ovoj bazi projekata nema spomenute korelacije ukupnog troška građevinsko-obrtničkih radova i udjela završnih radova.

Ako se vratimo na sliku 1 i prikaz odnosa pojedinih troškova u prodajnoj cijeni kvadrata novoizgrađenog stambenog objekta i prikažemo dobivene rezultate, dobijemo odnos na slici 2:
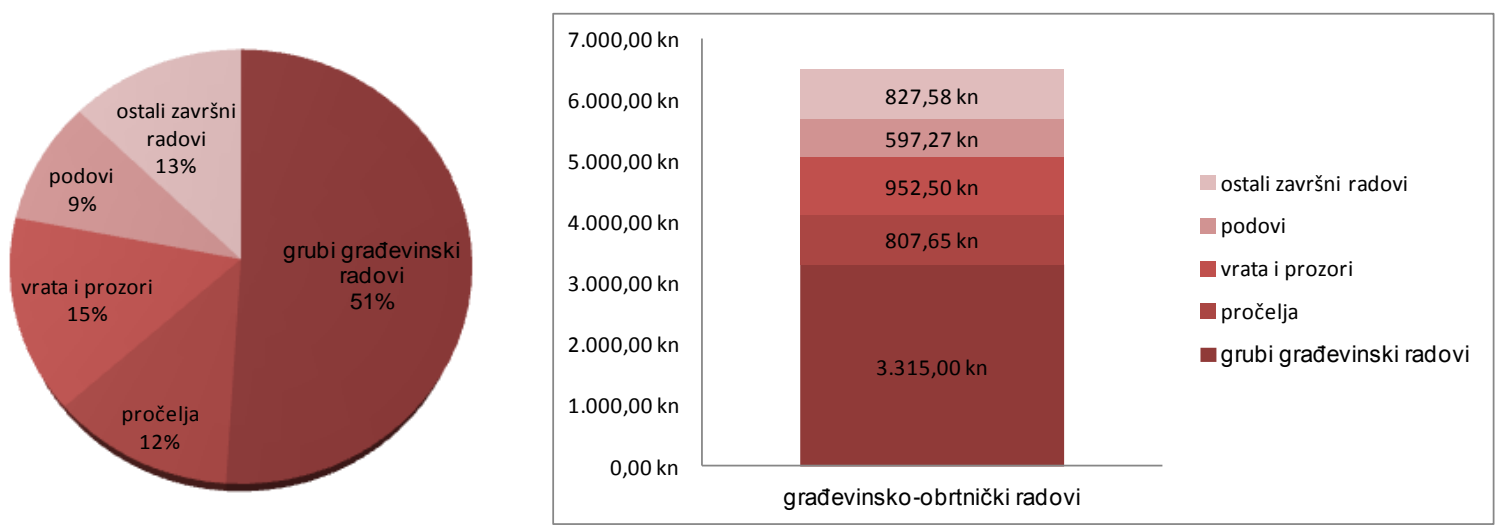

\section{Slika 2 - Odnos završnih i grubih građevinskih radova u stanogradnji izraženih po $\mathrm{m}^{2}$ stambenog prostora}

Prema danom grafičkom prikazu na slici 2 može se zaključiti da obrada pročelja i zatvaranje (vrata i prozori) građevine nosi znatan udio u troškovima završnih radova, ali i građevinsko-obrtničkih radova općenito, točnije udio je oko $27 \%$. Zanimljivo je da ranija istraživanja udjela troškova izgradnje višeetažnih stambenih zgrada pokazuju kako je udio troškova prozora i vrata neovisan o broju etaža, tj. broj etaža višeetažne stambene zgrade neće povećati udio troškova prozora i vrata [11], dok ukupna prodajna cijena $\mathrm{m}^{2}$ pada s visinom zgrade [12].

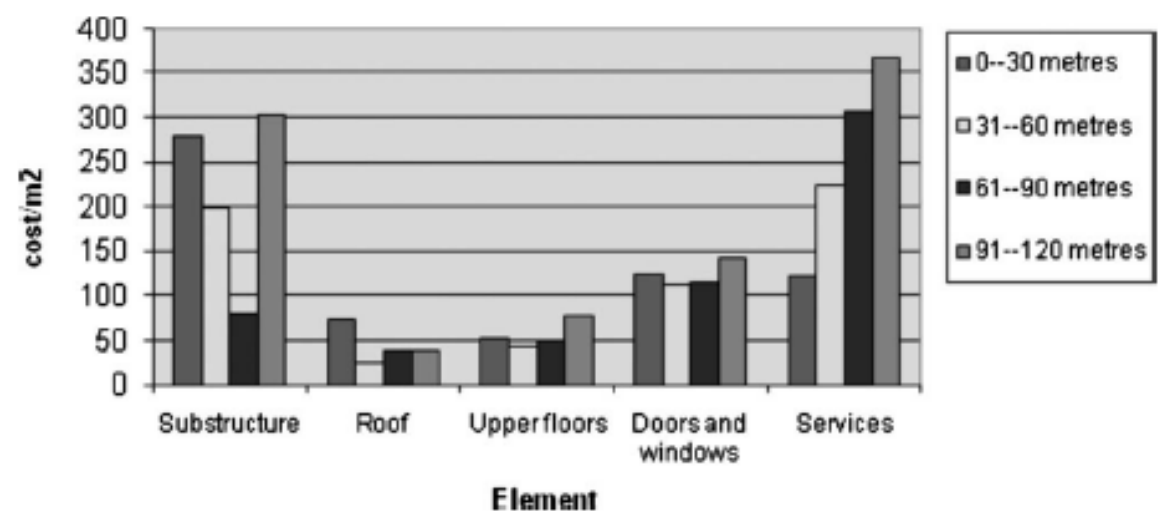

Slika 3 - Udjeli pojedinih dijelova novoizgrađenih višeetažnih stambenih zgrada [11] 


\subsection{Odnosi utrošaka resursa kod troškovnički značajnih karakterističnih vrsta radova u grupi završnih radova}

Zanimljiva je i analiza troškovnički izdvojenih, značajnih stavki karakterističnih vrsta završnih radova, gdje je promatran odnos utroška resursa za svaku stavku. Analiza je provedena korištenjem računalnog programa GALA tako da su se prvo odredile karakteristične vrste završnih radova u visokogradnji, a zatim prepoznale najčešće stavke tih radova. Određen je faktor rada u visokogradnji (pretpostavljen 4,0), satnice rada svih grupa radnika su pretpostavljene najviše koje su trenutačno zabilježene u građevinskim poduzećima u Republici Hrvatskoj, i na kraju, za prvo bilježenje odnosa utrošaka resursa pretpostavile su se najniže cijene materijala na tržištu. Sljedeće bilježenje odnosa utrošaka resursa je bilo uz $10 \%$-tno povećanje cijena materijala i zatim uz $20 \%$-tno povećanje cijena materijala. Razmatrani odnosi utrošaka resursa rada i materijala, uz zanemariv utrošak strojeva, prikazani su u tablici 4. Može se zaključiti da ove vrste radova nisu, kako se ranije vjerovalo, u potpunosti ovisne o izboru i tržišnoj cijeni materijala (slika 4).

Tablica 4 - Tablica odnosa utrošaka resursa karakterističnih vrsta završnih radova

\begin{tabular}{|c|c|c|c|c|c|c|}
\hline \multirow{2}{*}{ vrsta završnih radova } & \multicolumn{2}{|c|}{ minimalna cijena materijala } & \multicolumn{2}{|c|}{$\begin{array}{c}\text { 10\% povećanje cijene } \\
\text { materijala }\end{array}$} & \multicolumn{2}{c|}{$\begin{array}{c}20 \% \text { povećanje cijene } \\
\text { materijala }\end{array}$} \\
\cline { 2 - 7 } & $\%$ rad & $\%$ materijal & $\%$ rad & $\%$ materijal & $\%$ rad & $\%$ materijal \\
\hline \hline Fasaderski radovi & 92,58 & 7,37 & 90,61 & 9,34 & 84,22 & 15,74 \\
\hline Soboslikarski radovi & 75,31 & 24,70 & 73,86 & 26,13 & 72,52 & 27,48 \\
\hline Krovopokrivački radovi & 62,26 & 37,75 & 60,63 & 39,34 & 59,16 & 40,85 \\
\hline Keramičarski radovi & 55,82 & 44,18 & 54,02 & 45,96 & 52,45 & 47,55 \\
\hline Izolaterski radovi & 53,39 & 46,61 & 51,74 & 48,24 & 50,25 & 49,76 \\
\hline
\end{tabular}

minimalna cijena materijala

$10 \%$ povećanje cijene materijala

$20 \%$ povećanje cijene materijala

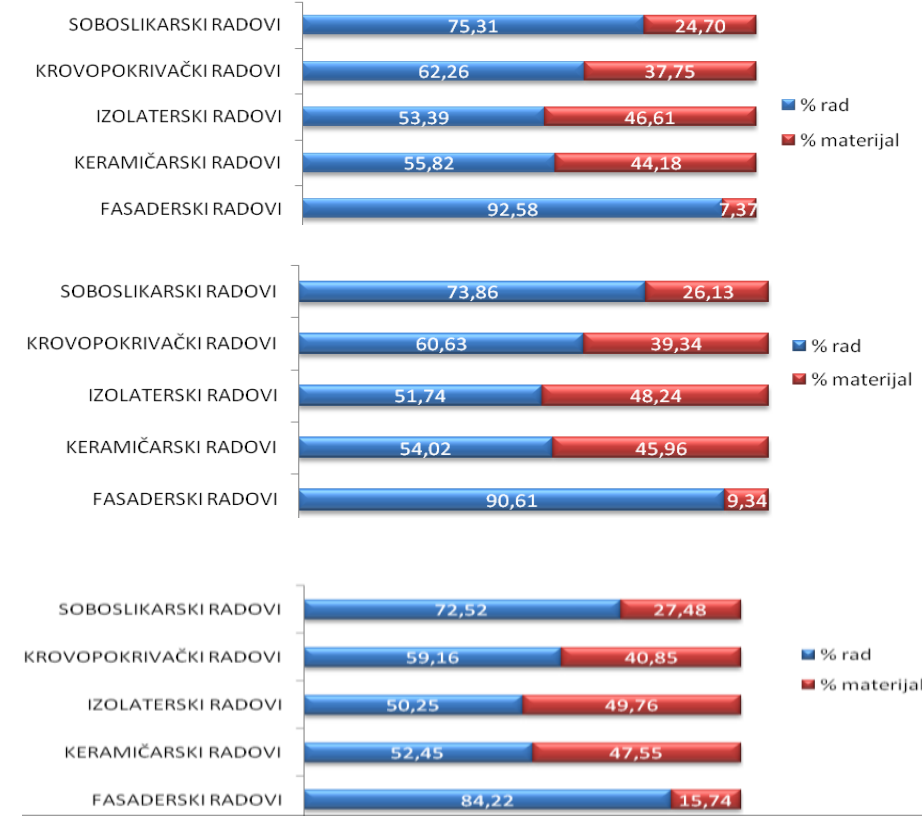

Slika 4 - Prikaz odnosa utroška resursa uz 10\%-tno povećanje troškova materijala 
Planiranje troškova obrtničkih radova je rizičan i složen posao, jer u fazi sklapanja ugovora, ako se ugovor sklapa tradicionalno i za cjelokupan projekt izgradnje ili adaptacije, vrlo često nisu još ni poznati svi podizvođači. Problem koji je suštinski trivijalan, u praksi se pokaže vrlo kompleksan. Stoga, dobrom koncepcijom kako projektnog zadatka tako i ugovora, problem planiranja troškova završnih radova postaje jednostavniji.

\section{Zaključak}

Kako se u radu i naglašavalo, podjela građevinskih radova u grupe i podgrupe je krucijalna i treba biti u funkciji planiranja troškova građevinskih radova. Ovo je vrlo bitan zahtjev, jer da bi mogli planirati troškove ujedno i s aspekta vremenskog planiranja radova i vremenskog planiranja troškova, on mora biti ispunjen. Tijekom istraživanja susreli smo se s temeljnim problemom struke, s nestandardiziranom podjelom vrsta u grupe radova, što naravno dovodi do vrlo varijabilnog udjela i omjera troškova završnih radova u grupi građevinsko-obrtničkih radova. Motivacija rada je i bila ta da se pokaže konfuzno stanje grupiranja i raspon udjela završnih radova, što u stvari ne bi trebali biti.

Dobiveni udjeli završnih radova pokazuju nam da prema prihvaćenoj podjeli ti radovi imaju značajan udio u troškovima građenja višeetažne stambene zgrade, te da bi se prema tome trebalo voditi računa prilikom ugovaranja građevinskih radova i o planiranju troškova. Ako znamo da je gotovo $40 \%$ udio završnih radova, a koji uglavnom otpada na podugovaračke ugovore, onda tradicionalni način ugovaranja dolazi u pitanje i nameće se rješenje konzorcija kao mogućeg produktivnijeg rješenja ugovaranja građevinskih radova. Jasno je da su završni radovi i u funkciji općeg dojma o građevini, dakle ova grupa radova je često vremenski pritisnuta, što ugrožava traženu kvalitetu radova.

Prilikom planiranja troškova građevinskih radova treba voditi računa i o vremenskom planu radova i troškova. Također, pokazalo se da s obzirom na veliko rasipanje udjela završnih radova pri adaptacijama radi širokog spektra obujma i vrsta zahvata, na ovaj način nema smisla izražavati udjele troškova završnih u odnosu na ukupne troškove građevinsko-obrtničkih radova, tj. da bi se mogli uspoređivati potrebno je usporedbe vršiti istovremeno i prema vrsti zahvata i prema namjeni objekta.

\section{Literatura}

[1] Klepac, J. 1988: Organizacija građenja, Građevinski institut, Zagreb

[2] Simović, V. 2002: Leksikon građevinarstva, Masmedia, Zagreb

[3] Ćirović, G., Luković, O. 2007: Građevinska ekonomija, Visoka građevinsko-obrtnička škola u Beogradu, Beograd

[4] Aničić, D. 2004: Planiranje uporabnog vijeka građevina (prijevod norma niza ISO $15686 \mathrm{~s}$ autorskim uvodom i komentarima), separat iz Građevnog godišnjaka 2003/04, Hrvatski savez građevinskih inženjera, Zagreb

[5] Lacković, V., Zagorec, M. 2004: Trajnost parketa u zgradama, Građevinar 56 (9): 555-560.

[6] Zakon o prostornom uređenju i gradnji (NN 175/03)

[7] Martinec, N. et al. 2010: Struktura troškova građevinskih radova u visokogradnji, Građevinar 62 (4): 307311.

[8] Krapfenbauer, R., Krapfenbauer, T. 2006: Građevinske tablice, Sajema d.o.o., Zagreb

[9] Državni zavod za statistiku Republike Hrvatske 2011: Hrvatska u brojkama 2011, Zagreb

[10] Juran, J. M., Gryna, F. M. 1999: Planiranje i analiza kvalitete: od razvoja proizvoda do upotrebe, Mate d.o.o. Zagreb

[11] Blackman, I. Q., Picken, D. H. 2010: Height and Construction Costs of Residential High-Rise Buildings in Shanghai, Journal of Construction Engineering \& Management, vol. 136, pp. 1169-1180.

[12] Picken, D. H., llozor, B. D. 2003: Height and construction costs of buildings in Hong Kong, Construction Management \& Economics, vol. 21, pp. 107-111. 